\title{
Effect of Storage Duration on Physicochemical and Antibacterial Activities of Sweet Corn-based SynbioticYogurt with Honey
}

\author{
Musyirna Rahmah Nasution* and Winda Sri Wahyuni
}

Farmasi, Sekolah Tinggi Ilmu Farmasi Riau, Pekanbaru, 28928, Indonesia

*Corresponding author: musyirnarahmah@stifar-riau.ac.id

DOI: $10.29303 /$ aca.v3i2.38

\author{
Article info: \\ Received 19/06/2020 \\ Revised 24/09/2020 \\ Accepted 26/09/2020 \\ Available online 18/10/2020
}

\begin{abstract}
Abbreviations:
SNI: Standar Nasional

Indonesia (Indonesia National

Standard); MPN: Most

Probable Number
\end{abstract}

\begin{abstract}
Synbiotic yogurt is fermented milk containing probiotics and prebiotics. The quality of symbiotic yogurt products during cold storage must meet the SNI quality requirements (2981-2009). This study aimed to find the effect of yogurt storage duration on physicochemical properties and antibacterial activity for the best yogurt storage time. In this study, synbiotic yogurt was made from sweet corn, honey, and full cream milk as prebiotics and Lactobacillus acidophilus and Bifidobacterium bifidum as probiotics. The tests carried out include testing total coliform, total lactic acid bacteria, degree of acidity $(\mathrm{pH})$, total titrated acid, organoleptic quality, and antibacterial activity. The tests were carried out on days $0,5,10,15$, and 20 . The results showed that storage duration affected product quality and antibacterial activity. The best storage duration for yogurt was found to be ten days, where the yogurt stored for ten days found to have a total coliform of $0 \mathrm{APM} / \mathrm{g}$, total lactic acid bacteria of $2.81 \times 1012$, total lactic acid of $1.684 \%$, $\mathrm{pH}$ value of 3.5 and was still preferred and could be accepted by the panelists, based on the organoleptic assessments. The yogurt stored for ten days also gave the largest average inhibition diameter of $21.78 \mathrm{~mm}$ with the category 'very strong' against Escherichia coli and $22.13 \mathrm{~mm}$ with the classification 'very strong' against Salmonella typhi. The yogurt stored for up to 10 days still met the SNI yogurt quality standard requirements (2981: 2009).
\end{abstract}

Keywords: yogurt, sweet corn, lactic acid bacteria, probiotic

Citation:

Nasution, M. R. \& Wahyuni, W. S. (2020). Effect of storage duration on physicochemical and antibacterial activities of sweet corn-based synbiotic yogurt with honey. Acta Chimica Asiana, 3(2), 174-180. DOI: 10.29303/aca.v3i2.38

\section{INTRODUCTION}

Sweet corn (Zea mays L.) contains high carbohydrates and reducing sugars, allowing it to be an ingredient to produce yogurt. The report underlined that the carbohydrates in corn kernels contain reducing sugars (glucose and fructose), sucrose, polysaccharides, and starch. The sweet corn endosperm contains sugar and starch about 5$6 \%$ and $10-11 \%$, respectively, while ordinary corn contains only $2-3 \%$ or half of the sweet one. High reducing sugars in sweet corn can be a source of energy for bacteria that carry out the fermentation process [1].

Prebiotics are indigestible food components that provide food for lactic acid bacteria for their growth. Honey acts as a source of prebiotics. The addition of honey to sweet corn yogurt improves the quality and nutritional value of corn-based yogurt and increases organoleptic properties, according to the panelists [2].

A functional food, yogurt has many health benefits because of its probiotic content. Probiotic bacteria improve the human immune system, help the nutritional absorption, help lactose digestion for people with lactose intolerance, and shorten diarrhea duration [3,4]. Probiotic bacteria can suppress the frequency of diarrhea. Examples of them are L. acidophilus, B. bifidum, and Enterococcus faecium [5]. They are also useful in the prevention and treatment of gastrointestinal diseases [6]. 
Diarrhea can be caused by bacteria-contaminated food. The most common bacteria that cause foodborne infections are Escherichia coli and Salmonella typhi [7].

One of the developments of functional food today is synbiotic food, which combines probiotics with prebiotics [8]. Synbiotic yogurt made from sweet corn (Zea mays L.) with the addition of $12 \%$ honey has antibacterial activity against E. coli and S. typhi with an average resistance diameter of $20.85 \mathrm{~mm}$ and $27.90 \mathrm{~mm}$ [9]. Referring to Nazri, the inhibition above $20 \mathrm{~mm}$ falls to the very strong category [10].

Physical properties are one of the criteria for determining the quality of fermented milk; these properties are modified with the presence of lactic acid produced by lactic acid bacteria. The acid affects the electrostatic charge of casein so that protein-protein interactions are strengthened due to decreased electrostatic repulsion and binding of calcium to casein to spur bonding.

Gel started by combining casein micelle networks due to the acidification process by lactic acid bacteria; its strength only comes from the number and strength of the bonds between casein-casein. This bond's strength is easily damaged due to mechanical treatment, so it can affect the binding capacity of water, syneresis level, texture, and viscosity of yogurt during storage due to the destabilization process of casein by lactic acid, which forms the structure and consistency of fermented milk. The casein destabilization process can affect the physical properties of yogurt [11]. The increased growth of probiotic bacteria by prebiotic substrates is beneficial to health, especially to overcome bacterial pathogen infections.

This study aimed to investigate the effect of storage time of the synbiotic yogurt on the quality products and antibacterial activity. The results provide information about the best yogurt storage time where yogurt is still suitable for consumption, favored by panelists, has antibacterial activity, and can meet SNI's quality requirements (2981-2009).

\section{MATERIALS AND METHODS}

\section{Materials}

The materials used in this study were sweet corn (Zea mays L.) and honey. Other materials used were full cream milk powder, BAL probiotic culture $(B$. bifidum BRL-130 and L. acidophilus FNCC-0051) obtained from the Center for Food and Nutrition Study at Universitas Gajah Mada, MRS agar (de MAN, ROGOSA, and SHARPE), MRS broth (deMAN, ROGOSA, and SHARPE), Lactose Broth (LB), ATC-25923 E. coli, S. typhi, Nutrient Agar (NA), sodium hydrogen phthalate, phenolphthalein (PP), distilled water, $0.9 \% \mathrm{NaCl}$, and other chemical ingredients used in the analysis
The tools used in the manufacture and study of sweetcorn-based synbiotic yogurt with honey were pans, stirrers, stoves, bottle containers, refrigerators, spectrophotometers (Genesys 10 $\mathrm{UV} ®), \mathrm{pH}$ meter $\left(\mathrm{pHep}{ }^{\circledR}\right)$, micropipette $\left(\mathrm{Nesco}^{\circledR}\right)$, hot plate(Torrey Pines Scientific ${ }^{\circledR}$ ), Laminar Flow Cabinet (JSR Model JSCB-900SL $®)$, oven (Memmert $\left.{ }^{\circledR}\right)$, incubator(Memmert $\left.{ }^{\circledR}\right)$, vortex (As One Tube Mixer TRIO HM-2F®), colony counter (Suntex Colony Counter 570®), autoclave(GEA Model YX-280B®), analytic scales (Shimadzu AUW220®), measuring cup (Iwaki Pyrex®), Erlenmeyer (Iwaki Pyrex®), the Durham cylinder, Petri dish, volume pipette, burette, stative, and other glassware.

\section{Methods}

\section{Preparation of corn-based yogurt}

We used a standard method of making yogurt. Briefly, sweet corn was cleaned from the skin and hair. Corn kernels that were still attached to the cob were washed with distilled water to remove impurities that were still attached. The clean corn was then boiled at $100^{\circ} \mathrm{C}$ for 9 minutes with distilled water. Then the corn kernels are peeled off the cobs. Corn shells were then blended to increase the particles' surface area, making it easier for fruit juices to seep out. The crushing process was done with corn boiled water with a ratio of corn kernels to the water of 1:2 so that it became corn porridge. Sweet corn grits are filtered with a filter cloth to get sweet corn juice.

Sweet corn juice, as much as $1900 \mathrm{~mL}$, added with full cream milk powder as much as $12 \%(\mathrm{w} / \mathrm{v})$ of the volume of sweet corn juice, then was cooked to a temperature of $80^{\circ} \mathrm{C}$, then stirred homogeneously to get sweet corn milk. The sweet corn milk was divided into 12 sterile glass bottles, namely five bottles for hedonic testing with $100 \mathrm{ml}$ sweet corn milk each and seven bottles for other tests with 200 $\mathrm{ml}$ sweet corn milk each. Then, honey was added to the respective bottle as much as $12 \%(\mathrm{w} / \mathrm{v})$ of the sweet corn milk volume.

Subsequently, pasteurization was carried out at 80$85^{\circ} \mathrm{C}$ for 15 minutes, and then the results were allowed to cool. Then, work culture inoculation of B. bifidum and L. acidophilus in a ratio of $1: 1$ was carried out to as much as $5 \%$ of the volume of sweet corn milk. The starter concentration was referring to the research of Nofrianti [2]. Incubation was carried out for 18 hours at $37^{\circ} \mathrm{C}$. After the incubation is complete, yogurt was stored in a refrigerator with a temperature of $4-7^{\circ} \mathrm{C}$.

\section{Test of the quality of yogurt on the effect of storage time}

Several quality tests were conducted to see the effect of storage time of sweet-corn-and-honeybased synbiotic yogurt stored at $4-7^{\circ} \mathrm{C}$. The tests included total coliform, total lactic acid bacteria, total titrated acid, acidity, and organoleptic levels 
and antibacterial activity, which were carried out on the days of $0,5,10,15$, and 20 of storage. At each time of testing, yogurt was taken from the respective bottles - these tests were conducted in triplicate.

\section{Data analysis}

The results on several quality products during storage were analyzed descriptively and compared with SNI (2981: 2009) tables. Antibacterial activity test results in the form of the mean diameter of the inhibition area and the standard deviation.

\section{RESULTS AND DISCUSSION}

In this research, the plant used was sweet corn (Zea mays L.) because it has a high reducing sugar content as an energy source for lactic acid bacteria to carry out the fermentation process. Besides, it was also readily available at a relatively low price. Other sugar sources were also necessary to increase the activity of starter bacteria. Honey can provide a carbon source for the activities of $L$. acidophilus and B. bifidum. Lactic acid bacterial activities will increase with the presence of sugars that are needed for growth. Honey can be used as a prebiotic because of its oligosaccharides [12]. Prebiotics are food components that cannot be digested to be used by lactic acid bacteria as a food source to trigger their growth activities. L. acidophilus can grow sufficiently with the availability of lactose and other sugars found in making yogurt, while Bifidobacterium sp. can grow and metabolize properly if the supply of vitamins and free amino acids in the form of peptides is sufficient [1].

In the yogurt making process, corn juice is added with full cream milk powder as much as $12 \%$. The results of synbiotic yogurt products can be seen in Figure 1. The addition serves as a lactose and protein source for the starter bacteria's activity and growth since sweet corn extract does not contain lactose or casein. Besides, it also can make yogurt to have the desired typical flavor. With the presence of a high level of milk fat in full cream milk powder, the typical yogurt flavor is expected to form optimally. The addition of $12 \%$ full cream milk powder in sweet corn raw material can produce the desired fermented beverage characteristics [13].

L. acidophilus and B. bifidum are probiotic lactic acid bacteria. Probiotic itself is a living microorganism that will provide benefits for its host when given in an appropriate amount. Krisnayudha stated that the LAB of the genus Lactobacillus and Bifidobacterium are suitable and best bacteria for prebiotics and activities against pathogenic bacteria [14]. Besides, yogurt that contains probiotic bacteria is believed to have physiological effects that are beneficial to consumers' health [15].
The use of a combination of two or more bacteria, namely L. acidophilus and B. bifidum, is known to have probiotic properties. Probiotic LAB has longer viability and can multiply [16]. The use of this probiotic $\mathrm{LAB}$ combination in the starter was expected to improve its work efficiency. The addition of a probiotic starter was also done because the starter bacteria are lactic acidproducing bacteria and play a role in the fermentation process. According to Winarno, the basis for making yogurt is the sugar fermentation process, especially lactose, into lactic acid and other acids. Lactic acid produced during the fermentation process can increase flavor and acidity or reduce $\mathrm{pH}$, in which the lower the $\mathrm{pH}$ will inhibit the growth of pathogenic microbes [17].

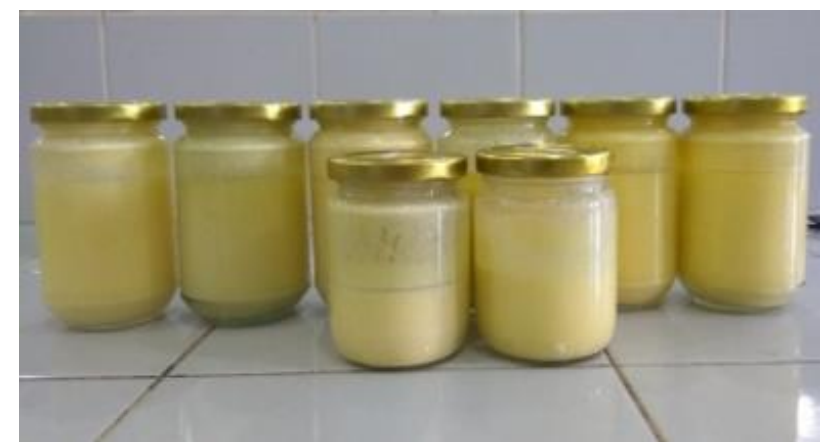

Figure 1. Synbiotic yogurt made from sweet corn and honey

\section{Total coliform}

The total coliform test is necessary for yogurt products. The presence of coliform can be used as an indication of the level of hygiene of a food product. The coliform test in this study was performed using the MPN (Most Probable Number) method, which was quantitative. Every tube that produced gas bubbles was thought to contain coliform bacteria. The test is considered positive if gas bubbles are seen on the Durham tube. The positive tubes are adjusted with the MPN Table to find out the amount of coliform in the sample. Yogurt SNI requirements for total coliform is no more than $10 \mathrm{APM} / \mathrm{g}$ (Table 1) [18].

The results showed that there were no coliform bacteria in yogurt during storage, marked by the absence of gas formation in the Durham tubes. In conclusion, synbiotic yogurt products during cold storage have met SNI quality requirements (29812009). A low pH of yogurt can cause this condition so that coliform bacteria cannot grow. Tamime and Robinson state that coliform groups cannot survive in low $\mathrm{pH}$, low storage temperatures, and with the presence of LAB metabolic substances such as antimicrobial substances and lactic acid so that the possibility of coliform bacteria in yogurt is very low) [19]. 


\section{Total lactic acid bacteria}

The method used was the Pour Plate method. The total LAB test aimed to see the growth of lactic acid bacterial colonies during storage. LAB activity increased until the $10^{\text {th }}$ day of storage, which amounted to $2.81 \times 10^{12}$. It was presumed that the bacterial growth phase continued for ten days. Furthermore, there was a decrease in LAB amount during the $15^{\text {th }}$ to $20^{\text {th }}$ days of storage, suggesting that the bacteria come to the death phase.

The up and down of the number of lactic acid bacteria is influenced by the LAB availability to grow. The amount of substrate in milk raw material for fermentation is still available enough so that the bacteria were very active in reproducing themselves. However, the substrate amount decreases so long that the bacteria are relatively inactive, and the bacteria have passed the logarithmic phase (20).

According to SNI (2009), the minimum total level of lactic acid bacteria in yogurt is $10^{7}$. The research results show that the total lactic acid bacteria obtained were more than the set standard, indicating that the starter grew well during the fermentation process.

Table 1. Physicochemical analysis and antibacterial activity of synbiotic yogurt made from sweet corn and honey for 20

\begin{tabular}{|c|c|c|c|c|c|c|}
\hline \multirow{2}{*}{ Parameters analysis } & \multirow{2}{*}{ SNI } & \multicolumn{5}{|c|}{ Storage day } \\
\hline & & 0 & 5 & 10 & 15 & 20 \\
\hline Total coliform (APM/g) & Max. 10 & 0 & 0 & 0 & 0 & 0 \\
\hline $\begin{array}{l}\text { Total lactic acid bacteria (LAB) } \\
(\mathrm{cfu} / \mathrm{ml})\end{array}$ & Min. $10^{7}$ & $1.66 \times 10^{12}$ & $2.01 \times 10^{12}$ & $2.81 \times 10^{12}$ & $1.17 \times 10^{12}$ & $\begin{array}{l}0.72 \\
\mathrm{x} 10^{12}\end{array}$ \\
\hline $\mathrm{pH}$ & - & 3.7 & 3.6 & 3.5 & 3.4 & 3.3 \\
\hline Total titrated acid (\%) & $0.5-2.0$ & $1.477 \%$ & $1.566 \%$ & $1.684 \%$ & $1.743 \%$ & $1.802 \%$ \\
\hline \multirow{2}{*}{ Hedonic (color) } & \multirow{4}{*}{ Normal/typical } & $(3.8)$ & $(3.7)$ & (3.6) & (3.6) & (3.6) \\
\hline & & Yellow & Yellow & Yellow & Yellow & Yellow \\
\hline \multirow{2}{*}{ Hedonic (aroma) } & & $(2.9)$ & $(2.9)$ & $(2.8)$ & $(2.7)$ & $(2.6)$ \\
\hline & & Typical & Typical & Typical & Typical & Typical \\
\hline \multirow{2}{*}{ Hedonic (flavor) } & \multirow{2}{*}{ Sour/typical } & $(3.4)$ & $(3.3)$ & $(2.8)$ & $(2.3)$ & $(2.2)$ \\
\hline & & Sour & Sour & Sour & Very sour & Very \\
\hline \multirow{2}{*}{ Hedonic (texture) } & \multirow{2}{*}{$\begin{array}{l}\text { Viscous-solid } \\
\text { liquid }\end{array}$} & (3.6) & (3.5) & $(3.2)$ & (3.1) & $(2.8)$ \\
\hline & & Viscous & Viscous & Viscous & Viscous & Viscous \\
\hline $\begin{array}{l}\text { Antibacterial activity (S. typhi) } \\
(\mathrm{mm})\end{array}$ & - & 20.10 & 20.65 & 22.13 & 20.07 & 13.42 \\
\hline $\begin{array}{l}\text { Antibacterial activity (E. coli) } \\
(\mathrm{mm})\end{array}$ & - & 12.70 & 13.87 & 21.78 & 12.43 & 11.92 \\
\hline
\end{tabular}

\section{Acidity (pH)}

Measurement of acidity $(\mathrm{pH})$ is a critical assessment of the quality of yogurt. The $\mathrm{pH}$ value is related to the amount of acid contained in the yogurt. The test results show a decrease in $\mathrm{pH}$ with the duration of storage time. Lactic acid bacteria will hydrolyze the lactose in milk into a variety of simpler carbohydrate compounds, and with more extended storage, the formed lactic acid is also increasing, causing a decrease in $\mathrm{pH}$.

The fermentation process leads to an increase in microbial activity, decreased $\mathrm{pH}$, and an increase in acid levels in fermented products [21].

\section{Total titrated acid}

Lactic acid $\left(\mathrm{C}_{3} \mathrm{H}_{6} \mathrm{O}_{3}\right)$ is the largest acid component formed from fermentation by yogurt bacteria. The determination of total titrated acid was carried out by the alkalimetry method to determine the production of organic acids is expressed as lactic acid from probiotic microorganisms.

The results showed that a long time would affect the increase in total acid levels. It is due to the increased activity of lactic acid bacteria in degrading lactose into lactic acid. According to Resnawati, lactose is an energy source for the 
growth of LAB in fermented milk, which in the next process, will act as a producer of acid levels in fermented milk. The longer fermented milk is stored, the energy source, in the form of lactose, will be overhauled by LAB, and there will be an increase in the total acidity of the fermented milk [22].

The more extended storage period of fermented milk will increase BAL activity to convert lactose to lactic acid [23]. The highest yield of total acid produced was $1,802 \%$ on the $20^{\text {th }}$ day of storage. This value still meets the SNI standard but almost reaches $2 \%$. According to Winarno and Fernandez, the amount of lactic acid is correlated to the $\mathrm{pH}$ value; the lower the $\mathrm{pH}$ value, the higher the lactic acid produced. An increase in total lactic acid in harmony with a decrease in $\mathrm{pH}$ indicates the presence of probiotic cell metabolic activity [8].

\section{Colour}

One of the most significant physical parameters of a product is its color. The color of these food products also influences consumer favor of food products. From the average hedonic test results on the color of sweet corn yogurt stored for 20 days of storage, panelists' preference on the color of sweet corn yogurt has an average score of 3.8-3.5, with the category 'like'. During storage, there was no decrease in preference for the color of yogurt. The color of sweet corn yogurt has a distinctive color from the sweet corn raw material, which is yellow because it contains many carotene pigments [24].

\section{Aroma}

Yogurt has distinctive aroma characteristics such as sour aroma. This aroma arises because, during the fermentation process, there is a change in milk lactose into lactic acid by lactic acid bacteria.

The hedonic tests found that the average score of the panelists' preference (namely ten panelists) for yogurt's aroma for 20 days of storage was 2.9-2.6 with the category 'somewhat like'. The aroma produced is distinctive. SNI (2981: 2009) states that yogurt will create a normal-typical fragrance from acids formed during the fermentation process.

\section{Flavor}

The taste produced by sweet corn yogurt is a typical sour taste, following SNI (2981: 2009), that states that yogurt has acid-specific criteria, which is caused by cellular metabolism lactic acid bacteria that produce lactic acid.
The hedonic tests carried out by ten panelists showed that on the $10^{\text {th }}$ day, the average score of the panelists' preferences was 3.4-2.8, with the category 'somewhat like.' The preference decreased after the 20th day to an average score of 2.3-2.2, which falls to the category 'dislike'. There was an increase in TAT and a decrease in $\mathrm{pH}$ during the storage time, proving that the acid content was very abundant so that the panelist's acceptance of the taste of yogurt was significantly decreased. The decrease in $\mathrm{pH}$ caused the taste to become sourer due to lactic acid formation as the main product of lactic acid bacteria's metabolism.

\section{Texture}

The texture is one of the parameters that determine the quality of yogurt significantly. Good yogurt is viscous, smooth, and not broken, following SNI (2981: 2009) that states that yogurt is a viscous-solid liquid. The results of the assessment of the sweet corn yogurt texture at 0-5 days storages showed an average score of 3.6-3.5 with the category 'like'. Meanwhile, there was a decrease in panelist preferences for the yogurt stored between 10 to 20 days. The average score was 3.2-2.8 or 'somewhat like'.

\section{Antibacterial activity}

In testing antibacterial activity, E. coli and S. typhi, which are enteropathogenic bacteria most often cause diarrhea and contaminate food, were used [25].

The antibacterial activity on day 0 did not differ from the antibacterial activity on day 15 . Storage extension until the $20^{\text {th }}$ day significantly decreased the antibacterial activity.

Optimum antibacterial activity occurred at an extension of up to 10 days of storage because of the general nature of Salmonella typhi, which is sensitive to acids produced by lactic acid bacteria (Table 1). This activity is shown by the large diameter of the inhibition formed. On day ten, the antibacterial activity against Escherichia coli was the largest diameter. However, the antibacterial activity on day 0 was not different from on days 5, 15, and 20 . The antibacterial activity in yogurt is caused by lactic acid bacteria producing lactic acid, acetic acid, hydrogen peroxide, and bacteriocin during the fermentation process. The decrease in activity on the $20^{\text {th }}$ day occurred because the lactic acid bacteria were decreasing so that the production of lactic acid and $\mathrm{pH}$ were getting less [26]. 


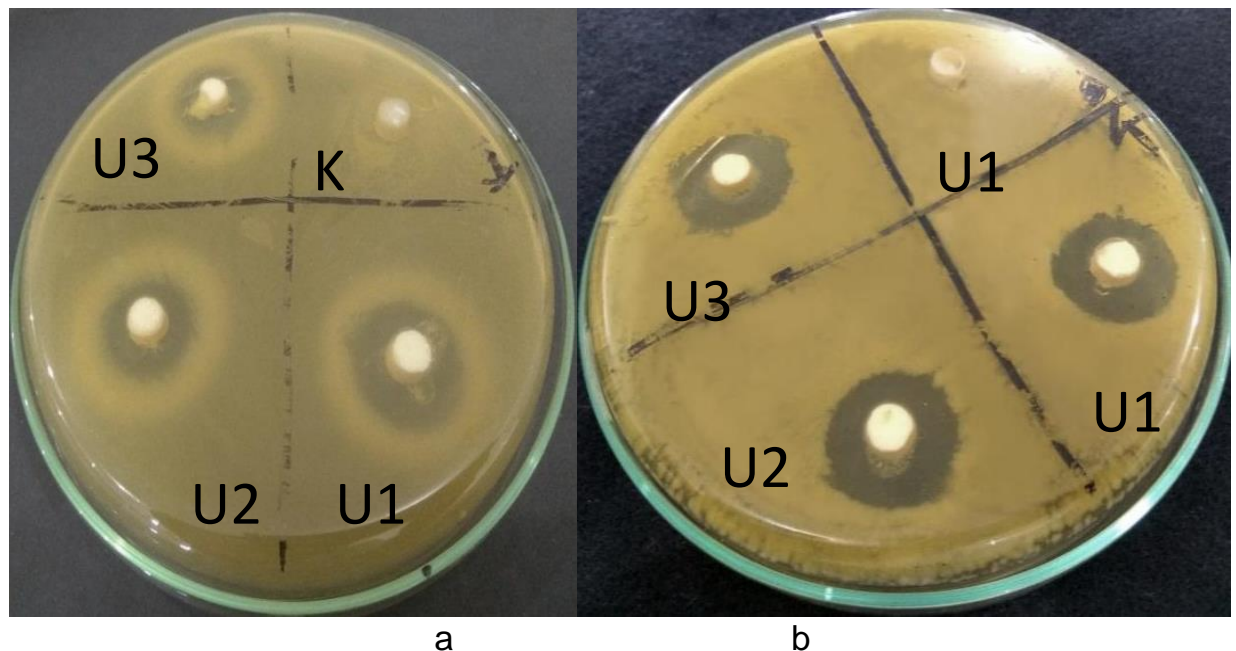

Figure 2. Corn-based yogurt antibacterial property. Inhibition zone against $S$. typhi (a) and E. coli (b) on the $10^{\text {th }}$ day with three replications (U1, U2, U3)

\section{CONCLUSION}

Yogurt that is stored for up to 10 days meets the requirements of the SNI yogurt quality standard (2981: 2009) and has antibacterial activity against S. typhi and E. coli that falls to very strong categories.

\section{REFERENCES}

[1] Sayuti, I., Sri, W., \& Dian K. S. (2013). Efektivitas Penambahan Ekstrak Ubi Jalar Ungu (Ipomoea batatas var. Ayamurasaki) dan Susu Skim terhadap Kadar Asam Laktat dan pH Yoghurt Jagung Manis (Zea mays L. saccharata) dengan Menggunakan Inokulum Lactobacillus acidophilus dan Bifidobacterium sp. Jurnal Biogenesis, 9(2), 21-27.

[2] Sert, D., Akin, N., \& Dertli, E. (2010). Effects of sunflower honey on the physicochemical, microbiological and sensory characteristics in set type yoghurt during refrigerated storage, International Journal of Dairy Technology, 64(1), 99-107. DOI: https://doi.org/10.1111/j.1471- 0307.2010.00635.x

[3] Amara, A. A., \& Shibl, A. (2015). Role of Probiotics in health improvement, infection control and disease treatment and management. Saudi pharmaceutical journal, 23(2), 107-114. DOI: 0.1016/j.jsps.2013.07.001

[4] Hegar, B., Waspada, I. M. I., Gunardi, H., \& Vandenplas, Y. (2015). A double blind randomized trial showing probiotics to be ineffective in acute diarrhea in Indonesian children. The Indian Journal of Pediatrics, 82(5), 410-414. DOI: 10.1007/s12098-014-1408-5

[5] Agustina, R., Kok, F. J., Van De Rest, O., Fahmida, U., Firmansyah, A., Lukito, W., ... \& Bovee-Oudenhoven, I. M. (2012). Randomized trial of probiotics and calcium on diarrhea and respiratory tract infections in Indonesian children. Pediatrics, 129(5), e1155-e1164. DOI: https://doi.org/10.1542/peds.2011-1379

[6] Applegate, J. A., Walker, C. L. F., Ambikapathi, R., \& Black, R. E. (2013). Systematic review of probiotics for the treatment of communityacquired acute diarrhea in children. BMC Public Health, 13(S3), S16. DOI: 10.1186/1471-2458-13S3-S16

[7] Al-Rwaily, M. A., Herzallah, S. M., Humeid, M. A., \& Yamani, M. I. (2005). Effect of dried dates extract on the growth and viability of Bifidobacteria in different milk types. Pakistan Journal of Nutrition, 4(3), 142-147. DOI: http://dx.doi.org/10.3923/pjn.2005.142.147

[8] Putra, I. M. W. A., Sukesi, K. A., \& Sulistyadewi, N. P. E. (2020). Antioxidant Capacity and $\alpha-$ Amylase Inhibition by Avocado (Persea americana Mill) Peel and Red Ginger (Zingiber officinale var. Rubrum) based Functional Drink. Acta Chimica Asiana, 3(1), 135-142. DOI: https://doi.org/10.29303/aca.v3i1.22

[9] Fazilah, N. F., Ariff, A. B., Khayat, M. E., RiosSolis, L., \& Halim, M. (2018). Influence of probiotics, prebiotics, synbiotics and bioactive phytochemicals on the formulation of functional yogurt. Journal of Functional Foods, 48, 387-399. DOI: https://doi.org/10.1016/j.jff.2018.07.039 
[10] Nazri, N. M., Ahmat, N., Adnan, A., Mohamad, S. S., \& Ruzaina, S. S. (2011). In vitro antibacterial and radical scavenging activities of Malaysian table salad. African Journal of Biotechnology, 10(30), 5728-5735.

[11] Mosilhey, S. H. (2003). Influence of different capsule materials on the physiological properties of microencapsulated Lactobacillus acidophilus. Inaugural-Dissertation, Departement of Food Technology, University of Bonn, Jerman.

[12] Ruiz-Matute, A. I., Brokl, M., Soria, A. C., Sanz, M. L., \& Martínez-Castro, I. (2010). Gas chromatographic-mass spectrometric characterisation of tri-and tetrasaccharides in honey. Food Chemistry, 120(2), 637-642. https://doi.org/10.1016/j.foodchem.2009.10.050

[13] Yasni, S., \& Maulidya, A. (2014). Development of corn milk yogurt using mixed culture of Lactobacillus delbruekii, Streptococcus salivarus, and Lactobacillus casei. HAYATI Journal of Biosciences, 21(1), 1-7. DOI: https://doi.org/10.4308/hjb.21.1.1

[14] Puspaningrum, D. H. D., \& Yuwono, C. S. M. (2019). Potential Tabah Bamboo Shoots Flour (Gigantochloa Nigrociliata Buse-Kurz) In Stimulate Lactic Acid Bacteria Growth., International Journal of Applied Science and Sustainable Development (IJASSD), 1(2), 6-15.

[15] Salminen, S., Lahtinen, S., \& Gueimonde, M. (2005). Probiotics and the reduction in risk of disease. Australian Journal of Dairy Technology, 60(2), 99.

[16] Trikoomdun, W., \& Leenanon, B. (2016). Production of corn milk yogurt supplemented with probiotics. International Food Research Journal, 23(4).

[17] Winarno, F.G., Wida, W.A., \& Weni, W. (2003). Flora Usus dan Yoghurt, M-Brio Press, Bogor.

[18] Badan Standarisasi Nasional. (2009). Syarat Mutu Yoghurt SNI 2981:2009, Badan Standar Internasional, Jakarta.

[19] Tamime, A. Y. \& Robinson, R. K. (1989). Yoghurt Science and Technology, Pergamon Press, Oxford.

[20] Sunarlim R, \& Usmiati, S. (2006). Sifat Morfologi dan Sensori Dadih Susu Sapi yang di Fermentasi Menggunakan Lacatobacillus plantarum dalam Kemasan yang Berbeda. Buletin Peternakan, 30(4), 208-216.
[21] Ao, X., Zhang, X., Shi, L., Zhao, K., Yu, J., Dong, L., ... \& Cai, Y. (2012). Identification of lactic acid bacteria in traditional fermented yak milk and evaluation of their application in fermented milk products. Journal of Dairy Science, 95(3), 1073-1084. DOI: https://doi.org/10.3168/jds.20114224

[22] Rolls, B. A., \& Porter, J. W. G. (1973). Some effects of processing and storage on the nutritive value of milk and milk products. Proceedings of the Nutrition Society, 32(1), 9-15.

[23] Maitimu, C. V., Legowo, A. M., \& Al-Barrii, A. N. (2013). Karakteristik mikrobiologis, kimia, fisik dan organoleptik susu pasteurisasi dengan penambahan ekstrak daun Aileru (Wrightia calycina) selama penyimpanan. Jurnal Aplikasi Teknologi Pangan, 2(1), 18-29.

[24] Xiaohua, D. (2002). Studies on Introducedvariety and High-yield Cultivation Techniques of Hybrid Corn. Journal of Maize Sciences, 2002(3), 71-73.

[25] Fadiah, R., Izzah, Z., \& Nasution, N. E. (2014). Aktivitas antibakteri kombinasi probiotik (Bifidobacterium bifidum dan Lactobacillus acidophilus) dengan infus daun jambu biji (Psidium guajava). Berkala Ilmiah Kimia Farmasi, 3(2), 16-22. 